\title{
Effectiveness Of Use Of Nesting On Body Weight, Oxygen Saturation Stability, And Breath Frequency In Prematures In Nicu Room Gambiran Hospital Kediri City
}

\author{
Miftakhur rohmah $^{1^{*}}$, Nurwinda Saputri ${ }^{2}$, Justitia Bahari ${ }^{1}$ \\ ${ }^{1}$ IIK STRADA Indonesia, Kediri, East Java, indonesia \\ ${ }^{2}$ University of Muhamadiyah Pringsewu \\ miftakh@iik-strada.ac.id
}

\begin{abstract}
Premature births are responsible for two-thirds of infant deaths due to lack of good adaptability to extrauterine life so that the prospects for the survival and health of infants are greatly threatened. Nesting is an innovation used in the NICU room made of baby swaddling cloth that is rolled up in such a way that is then positioned around the baby's body like a condition in the mother's womb. This study aims to determine the effectiveness of the use of nesting 5 and 7 days in maintaining the stability of oxygen saturation, breathing frequency and body weight in premature infants in the NICU Room at Gambiran City Hospital in Kediri. This study used aapproach quasi-experimental with pre-post test group design in the NICU Room at Gambiran City Hospital in Kediri for the period 1 May 2019 to 31 July 2019. The population was 30 preterm infants. With purposive sampling technique, there were 14 samples of preterm infants. Group 1 consisted of 7 infants performed nesting for 5 days and group 2 consisted of 7 infants performed nesting for 7 days. Data normality test uses the Kolmogoro-Smirnov Test. Independent $t$ test is used to test the effectiveness of using nesting on oxygen saturation, respiratory frequency stability and premature baby's weight. The results of the study in both groups $\mathrm{p}<\alpha(0.05)$, then $\mathrm{H}_{0}$ is rejected and $\mathrm{H}_{1}$ accepted. So it can be concluded that the use of nesting in premature babies is effective in stabilizing body weight, oxygen saturation, the frequency of breathing of premature babies.
\end{abstract}

Keywords: Premature, Nesting on body weight, Oxygen saturation, Breath frequency. 


\section{STRADA Jurnal Ilmiah Kesehatan}

DOI: $10.30994 /$ sjik.v9i1.275

ISSN: 2252-3847 (print); 2614-350X (online)

Vol.9 No.1. May 2020. Page.119-128

\section{BACKGROUND}

Preterm birth is responsible for two-thirds of infant deaths. Preterm or premature is defined as birth before 37 weeks' gestation, regardless of body weight (Bobak, 2015). Premature babies do not have the ability to adjust well to extrauterine life and the prospect of babies to have good survival or health can be severely threatened. The World Health Organization (WHO) states that babies born weighing less than 2500 grams and born after 37 weeks' gestation have better prospects for life than those born prematurely. LBW mortality is less than 5\% if the pregnancy lasts until the age of term (Bobak, 2015).

Problems that often occur in premature babies include being born with a low birth weight of less than 2500 grams, as compensation for the lack of fat reserves. Babies who are born full term will experience a weight loss of around $5-10 \%$ in the first 7 days. Peak weight loss occurs on the second day after birth. Research conducted by Davanzo et al explains that weight loss of $8 \%$ is the top safe limit for newborn weight loss. If weight loss is $\geq 8 \%$, it can increase the risk of mortality and morbidity in infants, such as hyperbilirubinemia and dehydration due to hypernatremia.

Based on East Java's health profile in 2016, 20,836 babies were born with a body weight $<2500 \mathrm{~g}$ out of 580,153 baby births, or around 3.6\%. In Kediri City, 127 babies were born with low birth weight from 4,324 babies born that year.

The number of low birth weight babies treated during the last three months in the Neonatus room at Gambiran City Hospital in Kediri (September - November 2018) obtained 98 data, with birth weight $<2500$ grams, 36 of them were treated in the NICU room and 15 of them died due to various complications ( Medical Record, 2019).

Premature babies are also very susceptible to hypothermia due to thin fat reserves under the skin and immature heat control centers in the brain (Zaviera, 2012). The hypothermic condition causes permanent central nervous system changes which eventually lead to mortality. Chilled babies spend calories to warm the body and vice versa make an effort to stabilize body temperature to normal. Hypothermia conditions cause increased oxygen consumption and if not fulfilled causes a hypoxic situation and causes tachycardia or bradycardia in response to decreased oxygenation. In premature neonates, the quantity of fluid loss through evaporation of the skin and respiratory tract is higher than in neonates born at term. In addition, neonates born prematurely have a greater extracellular component, leading to greater diuresis in premature neonates. This is what causes neonates born prematurely to experience a higher weight loss than neonates born at term. Whereas in neonates born less months, the decline can occur up to $15 \%$. Physiological weight loss does not occur after neonates aged 5-7 days and body weight increases at 1214 days (Rahardina, 2015).

Respiratory problems are one of the causes of death in babies born prematurely. Respiratory problems in infants are often associated with the condition of Respiratory Distress Syndrome (RDS), also called hyaline membrane disease (HMD), is the most common cause of morbidity and mortality in low birth weight infants that is often caused by prematurity. RDS incidence of about $5-10 \%$ is found in infants less than 50 months, $50 \%$ in babies weighing 500-1500 grams (Nur, 2010).

Interview with nurses from the NICU Room at Gambiran City Hospital in Kediri, obtained information that the use of nesting was done prematurely. Nesting is the use of tools shaped like a condition in the mother's womb made of linen and can be adjusted to the length of the baby's body. This tool is placed as a protector of the baby's position, maintaining changes in the baby's position caused by gravity. Nesting is one of the nursing 


\section{STRADA Jurnal Ilmiah Kesehatan}

DOI: $10.30994 /$ sjik.v9i1.275

interventions in giving the right position for neonates. Nesting can facilitate the development of premature babies in the form of physiological and neurological conditions. Nesting is a buffer in the sleeping position of the baby so that it stays in a position of flexion, this is intended to prevent drastic changes in the position of the baby that can result in loss of energy from the neonate's body.

Based on the above phenomenon, researchers are interested in conducting further research on "Effectiveness of Nesting Use on body weight, oxygen saturation stability, and breathing frequency in premature infants in the NICU room at Gambiran City Hospital in Kediri".

\section{OBJECTIVE}

This study aimed to determine Effectiveness of Nesting Use on body weight, oxygen saturation stability, and breathing frequency in premature infants in the NICU room

\section{METHODS}

Methods Themethod used is quasi-experimental withapproach one group pretest posttest. The sample in this study was a portion of premature infants who were in the NICU room at Gambiran City Hospital in Kediri for 1 month that met the criteria of premature babies with birth weight> 1500-2500 grams, who did not have respiratory disorders, babies who did not undergo surgery, were treated in incubator, premature babies who do not have central nervous system damage and do not experience congenital abnormalities. Sampling uses a purposive sampling technique. The implementation time is on May 1 to July 31, 2019. The instrument used to take the Oxygen Saturation variable is oximetry with a normal SPOindicator $288-95 \%$, the breath frequency variable uses a stethoscope with a normal RR indicator: 30-60x / min, the Weight variable Agency uses Infant scale digital instruments. Nesting was given for 30 minutes per day for 5 days in groups 1 and 7 days in group 2.

\section{RESULTS}

\section{Characteristics of Respondents}

This study sampled 14 premature infants treated in the NICU Room at Gambiran City Hospital in Kediri during the period of May 12019 to 31 July 2019. The characteristics of the respondents are then presented in the form of the following table.

Table 1 Characteristics of Respondents by Age of Pregnancy

\begin{tabular}{clcc}
\hline $\begin{array}{c}\text { Age of Pregnancy } \\
\text { (weeks) }\end{array}$ & Grup & n & \% \\
\hline $29-31$ & Group 1 & 2 & 14.23 \\
& Group 2 & 3 & 21.47 \\
$32-36$ & Group 1 & 5 & 35.71 \\
& Group 2 & 4 & 28.57 \\
Total & & 14 & 100 \\
\hline
\end{tabular}

Source: Primary Data, 2019

Based on the above table, most respondents were born with 32-36 weeks' gestation. Namely $35.71 \%$ in group 1 and $28.57 \%$ in group 2. 


\section{STRADA Jurnal Ilmiah Kesehatan}

DOI: $10.30994 /$ sjik.v9i1.275

ISSN: 2252-3847 (print); 2614-350X (online)

Vol.9 No.1. May 2020. Page.119-128

\begin{tabular}{|c|c|c|c|c|}
\hline $\begin{array}{l}\text { Weight } \\
\text { (grams) }\end{array}$ & Birth & Grup & $\begin{array}{l}\text { Total } \\
\text { n }\end{array}$ & $\%$ \\
\hline \multirow[t]{2}{*}{$1500-1999$} & & Group 1 & 2 & 14.23 \\
\hline & & Group 2 & 4 & 28.57 \\
\hline \multirow[t]{2}{*}{$2000-2500$} & & Group 1 & 5 & 35.71 \\
\hline & & Group 2 & 3 & 21.49 \\
\hline Total & & & 14 & 100 \\
\hline
\end{tabular}

Source: Primary data, 2019.

Based on table 2 above, most respondents were born with a body weight of 2000-2500 grams. Namely $57.2 \%$., Where group 1 contributed $35.71 \%$ and group 2 contributed $21.49 \%$.

Table 3 Characteristics of Respondents by Gender

\begin{tabular}{cccccc}
\hline \multicolumn{2}{c}{ Variable } & Men & \% & Women & \% \\
\hline \multirow{2}{*}{ Gender } & Group 1 & 3 & 42.86 & 4 & 57.14 \\
& Group 2 & 2 & 28.57 & 5 & 71.43 \\
\hline
\end{tabular}

Source: Primary data, 2019.

In table 3 it can be seen that the number there were more female respondents in each group than male respondents, which was $57.14 \%$ in group 1 . While in group 2 there were $71.43 \%$ respondents were female.

Table 4 Equality of Research Respondents by Pregnancy Age

\begin{tabular}{llcccccc}
\hline \multicolumn{1}{c}{$\begin{array}{l}\text { Characteristics } \\
\text { Variable }\end{array}$} & $\begin{array}{l}\text { n } \\
(\boldsymbol{\%})\end{array}$ & Mean & Median & SD & Min-max & P-value \\
\hline $\begin{array}{l}\text { Pregnancy } \\
\text { Age }\end{array}$ & Group 1 & $7(50)$ & 33 & 33 & 1.88 & $29-35$ & 0.272 \\
& Group 2 & $7(50)$ & 33 & 33 & 2.03 & $29-35$ & \\
\hline
\end{tabular}

Source: Primary data, 2019.

Based on table 4, the mean gestational age in group 1 and group 2 was 33 weeks. The results of the normality test data using the Kolmogorov-Shmirov Test, obtained gestational age is equivalent to $\mathrm{p}$ value $>0.05$ which means there is equality at the gestational age of the two groups. The mean and median in the two groups were the same, ie 33 weeks, which means the data distribution is normal.

Based on these data the researchers concluded that there was equality in group 1 and group 2. Where group 1 was the baby to be nested for 5 days and group 2 was nested for 7 days.

\section{Characteristics of Variables}

Characteristics of each variable studied are oxygen saturation, respiratory frequency and body weight measured values include mean, median and mode aimed at determining the normality of the data. The data normality test uses the Kolmogorov-Smirnov Test. 


\section{STRADA Jurnal Ilmiah Kesehatan}

DOI: $10.30994 /$ sjik.v9i1.275

ISSN: 2252-3847 (print); 2614-350X (online)

Vol.9 No.1. May 2020. Page.119-128

Table 5 Analysis of Oxygen Saturation Data, Respiratory Frequency and Weight of Premature Babies Before Using Nesting

\begin{tabular}{ccccccc}
\hline & Variables & Mean & Median & Mode & SD & P value \\
\hline $\begin{array}{c}\text { Oxygen } \\
\text { Saturation }\end{array}$ & Group 1 & 91.14 & 90 & 90 & 1.96 & 0.755 \\
& Group 2 & 91 & 90 & 90 & 1.51 & \\
$\begin{array}{c}\text { Respiratory } \\
\text { Frequency }\end{array}$ & Group 1 & 64,43 & 65 & 65 & 2.38 & 0.85 \\
Group 2 & 64 & 64 & 64 & 1.6 & \\
Bedy & Group 1 & 1977.14 & 2010 & 2010 & 206.31 & 0.177 \\
& Group 2 & 1968.57 & 1950 & 1950 & 203.73 & \\
\hline
\end{tabular}

Source: Primary data, 2019.

In the table 4.5 found the average oxygen saturation prior to the installation of nesting in group 1 was $91.14 \%$ and group 2 was $91 \%$. Equivalence test results found that the oxygen saturation of the two groups is equivalent to $\mathrm{p}$ value $>0.05$. Thevalues are modethe and median same meaning the data distribution is normal.

The mean respiratory frequency before nesting in group 1 was $64.43 \mathrm{x} / \mathrm{min}$ and was $64 \mathrm{x}$ group 2/ min. Both groups have the same mean and median mean the data distribution is normal. Equivalence test results $\mathrm{p}$ value $>0.05$.

The mean weight before nesting in group 1 was 1977.14 grams and group 2 was 1968.57 grams. Both groups have the samevalues mode and median meaning the data distribution is normal. Equivalence test results found that the weight of the two groups is equivalent to $p$ value $>0.05$.

Table 6 Analysis of Oxygen Saturation Data, Respiratory Frequency and Weight of Premature Babies After Using Nesting

\begin{tabular}{cccccc}
\hline \multicolumn{2}{c}{ Variable } & Mean & Median & Mode & SD \\
\hline $\begin{array}{c}\text { Oxygen } \\
\text { Saturation }\end{array}$ & Group 1 & 93.42 & 93 & 93 & 1.29 \\
$\begin{array}{c}\text { Respiratory } \\
\text { Frequency }\end{array}$ & Group 2 & 95.71 & 96 & 97 & 1.27 \\
& Group 1 & 58,14 & 59 & 59 & 2.59 \\
weight & Group 1 & 53.43 & 52 & 52 & 2.06 \\
& Group 2 & 1992.86 & 2020 & 2020 & 206.72 \\
& 1997.14 & 1970 & 1970 & 203.88 \\
\hline
\end{tabular}

In table 6 was found to mean oxygen saturation after the installation of nesting on group 1 was $93.42 \%$ and group 2 was $95.71 \%$,. The difference in mean increase in both groups was $2.29 \%$, whereas in group 2 the increase in saturation was more significant than in group 1 . The mean respiratory frequency after nesting in group 1 was $58.14 \mathrm{x} /$ minute and 


\section{STRADA Jurnal Ilmiah Kesehatan}

DOI: $10.30994 /$ sjik.v9i1.275

group 2 was $53.43 x$ / minute. In group 2 there was a better respiratory deceleration with a difference of $4.71 \mathrm{x} / \mathrm{min}$ from group 1 . The mean weight after nesting in group 1 was 1992.86 grams and group 2 was 1997.14 grams. Group 2 experienced an increase in the mean more than group 1 by 4.28 grams.

\section{Statistical}

Tests Testing the normality of the data in this study using the Kolmogorov-Smirnov test, where the normality test is a requirement or assumption of the parametric test.

This study uses an independent test, which is a comparative test to find out whether there are significant differences in mean or average between two free groups that have interval or ratio data scales where the source of data comes from different subjects. In this study an independent $t$ test was used to test the effectiveness of using nesting on oxygen saturation, respiratory frequency stability and body weight of premature infants. This test is used to determine the $\mathrm{p}$ value (probability value) of each variable tested.

Table 7 Effectiveness ofUse Nesting on Oxygen Saturation in Premature Babies

\begin{tabular}{ccccc}
\hline \multicolumn{2}{c}{ Oxygen Saturation Variables } & Mean & SD & P value \\
\hline Group 1 & Before & 91.14 & 1.96 & 0.001 \\
& After & 93.42 & 1.29 & \\
Group 2 & Before & 91 & 1.51 & 0.001 \\
& After & 95.71 & 1.27 & \\
\hline
\end{tabular}

Source: Primary data, 2019.

In table 7 it appears that in both groups there was a significant increase in mean oxygen saturation. In group 1 before the average oxygen saturation action $91.14 \%$ to $93.42 \%$. Group 2 before the average oxygen saturation action $91 \%$ to $95.71 \%$. In both groups the results count $\mathrm{p}(0.001)<\alpha(0.05)$, then $\mathrm{H}_{0}$ is rejected and $\mathrm{H}_{1}$ accepted. So it can be concluded that the use of nesting effectively maintains oxygen saturation in premature babies.

Table 8 Effectiveness ofUse Nesting on Respiratory Frequency in Premature Babies

\begin{tabular}{ccccc}
\hline \multicolumn{2}{l}{ Breathing Frequency Variables } & Mean & SD & P value \\
\hline Group 1 & Before & 64.43 & 2.38 & 0.002 \\
& After & 58.14 & 2.59 & \\
Group 2 & Before & 64 & 1.6 & 0.000 \\
& After & 53.43 & 2.06 & \\
\hline
\end{tabular}

Source: Primary data, 2019.

In table 8 it appears that in both groups there was a significant decrease in the average respiratory frequency. In group 1 prior to the mean respiratory frequency $64.43 \mathrm{x} /$ minute decreased to $58.14 \mathrm{x} /$ minute with $\mathrm{p}$ value 0.002 . Group 2 before the average respiratory frequency of $64 \mathrm{x} / \mathrm{min}$ fell to $53.43 \mathrm{x} / \mathrm{min}$, with a $\mathrm{p}$ value of 0,000 . In both groups the results count $\mathrm{p}(0.002)<\alpha(0.05)$, then $\mathrm{H}_{0}$ is rejected and 


\section{STRADA Jurnal Ilmiah Kesehatan}

DOI: $10.30994 /$ sjik.v9i1.275

ISSN: 2252-3847 (print); 2614-350X (online)

Vol.9 No.1. May 2020. Page.119-128

$\mathrm{H}_{1}$ accepted. So it can be concluded that the use of nesting is effective in reducing respiratory frequency in premature babies.

Table 9 Effectiveness ofUse on Nesting Premature Baby Body Weight

\begin{tabular}{ccccc}
\hline \multicolumn{2}{c}{ Variable Weight } & Mean & SD & P value \\
\hline Group 1 & Before & 1977.14 & 206.31 & 0.001 \\
& After & 1992.86 & 206.72 & \\
Group 2 & Before & 1968.57 & 203.73 & 0.000 \\
& After & 1997.14 & 203,8 & \\
\hline
\end{tabular}

Source: Primary data, 2019.

Table 9 shows that in both groups there was a significant increase in body weight. Where group 1 before the average weight of 1977.14 grams increased to 1992.86 grams with a $\mathrm{p}$ value of 0.001 . Whereas Group 2 before the mean weight action of 1968.57 grams increased by 28.57 grams to 1997.14 grams, with a $\mathrm{p}$ value of 0,000 . In both groups the results count $\mathrm{p}(0.001)<\alpha(0.05)$, then $\mathrm{H}_{0}$ is rejected and $\mathrm{H}_{1}$ accepted. So it can be concluded that the use of nesting in premature babies is effective in increasing body weight.

\section{DISCUSSION}

\section{Effect ofUse Nesting 5 and 7 Days Against Oxygen Saturation in Premature Babies}

Based on table 7 an increase in the average oxygen saturation after the use of nesting. In the group performed nesting for 5 days there was an increase in the average of $2.28 \%$ and in the group carried out nesting for 7 days the mean increased by $4.71 \%$.

This is in accordance with the theory that states that the exact position and anatomical is an important component in the care of the development of premature babies (Bowden, et al. 2000). Nesting functions as a support for the baby's body so that there is no drastic change in position in the baby that can result in a lot of energy loss. Can also prevent the incidence of hypoxia due to hypothermia or due to incorrect position which results in difficulty breathing (Zubaidah, 2012). So that oxygen saturation can be maintained within the normal range.

Stress is closely related to cortisol production which can reduce oxytocin production which affects parasympathetic control in the cardiorespiratory system (Zahra, et. Al., 2018). Babies use nesting as a support for sleep to stay in a flexed position. This position facilitates the baby to feel relaxed and not stressed due to changes in conditions outside the uterus, thereby reducing the frequency of breathing and increasing oxygen saturation.

In this study thegroup nesting for 7 days showed better oxygen saturation results than thegroup nesting for 5 days. This can be realized, with increasing age of the baby, the baby's ability to adapt to the environment also improves. Nevertheless, nesting facilitates the development of premature babies in suppressing stress byan environment based on developingdevelopmental care that supports the development of physiological conditions.

\section{Effect ofUse Nesting 5 and 7 Days Against Respiratory Frequency in Premature Babies}

Based on table 8 there was a decrease in the average respiratory frequency in both groups after nesting. In the group that wasnesting for 5 days there was a decrease in the average respiratory frequency by $3.71 \mathrm{x} /$ minute, whereas in thegroup nesting for 7 days there was a decrease in the average respiratory frequency which was more by $10.57 \mathrm{x} /$ minute. 


\section{STRADA Jurnal Ilmiah Kesehatan}

DOI: $10.30994 /$ sjik.v9i1.275

The results of this study are consistent with the theory that the baby's position affects the amount of energy expended by the body. The best position for premature babies is to do a flexion position because it will reduce metabolism in the body (Bowden, et. Al, 2000). The use of nesting facilitates the baby in maintaining a flexion position, namely by supporting the baby's body so that it is in the right and comfortable position. In babies with oxygen support, nesting helps maintain a position so as to maximize therapeutic delivery.

Premature babies have a very thin layer of subcutaneous fat, so hypothermia is easy and oxygen demand will be greater (Wong, et. Al., 2009). This is consistent with research conducted by Bayuningsih (2011), that nesting is able to maintain a warm body temperature so as to prevent respiratory stress due to hypothermia. Nesting is an environmental management method similar to KMC (kangaroo mother care) in infants whose conditions do not meet the KMC requirements.

The decrease in respiratory frequency is because the baby is calmer and increases sleep when nesting. It also shows a decrease in the stress level of infants due to deceleration of the body's cortisol level. Mooncey et al's research indicates that cortisol levels decrease by as much as $\pm 60 \%$ affecting the limbic area of the insular cortex in the brain, then resulting in the production of oxytocin which can calm and stabilize the cardiorespiratory system. When nesting, the baby is altered in a position so that it is not always in the supine position which can increase diaphragm compression. Infants are positioned flexibly so as to optimize the functioning of the baby's respiratory system (Zahra, et. Al., 2018).

The results showed that preterm infants undergoing nesting showed a more significant respiratory frequency deceleration than the first group. This can be influenced by the maturity of premature baby organs which is increasing. Nesting in this case helps to condition the baby's environment so that it remains conducive so that the energy it has can be maximized to support the development of premature babies so that it is faster in achieving optimal health conditions.

\section{Effect of Nesting Use 5 and 7 Days Against Premature Baby Weight}

Based on the results of the analysis in table 9 there was an increase in the average weight in both groups after nesting. In the nesting group for 5 days there was an average increase of 15.72 grams. In the nesting group for 7 days the average was 28.57 grams.

The baby's weight carried out by nesting longer showed better results, this is because the nesting method has a positive effect on maintaining the baby's weight (Anderson et al, 2003). The use of nesting intervention is done with the hope to maintain the energy released by the baby's body so that it is used optimally for growth and development. The researchers analyzed a number of studies, including concluding that nesting can reduce energy expenditure, accelerate emptying of stomach contents, increase nutrient absorption thereby reducing the incidence of significant weight loss.

Nesting is able to keep body temperature warm so as to prevent hypothermia (Bayuningsih, 2011). Warm ambient temperature in premature babies is needed for the efficiency of metabolism or the conservation of body energy as measured by calorie measurement (Zahra, et. Al., 2018).

Researchers also analyzed that the increase in baby's weight was influenced by several factors one of which was the baby's ability to absorb nutrients given both orally and parenterally. In premature babies who are cared for separately from their mothers, this 


\section{STRADA Jurnal Ilmiah Kesehatan}

DOI: $10.30994 /$ sjik.v9i1.275

nesting treatment is expected to be able to control stress that is exposed due to differences in extrauterine conditions.

Physiologically, infant weight gain is also influenced by the age of the baby, where babies tend to lose significant weight. Babies do not lose more than $10 \%$ of weight on the 5th day of birth. In neonates born less months, a decrease can occur up to 15\% (Rahardina, 2015).

The use of this nesting can help the baby in stabilizing the physiological functions of the body's metabolism by preventing stress, the baby in a pleasant position like conditions in the womb. As explained in previous research by Bayuningsih (2011), although in the study the changes that occurred were not significantly explained.

\section{CONCLUSION}

An increase in mean oxygen saturation significantly in both groups after nesting. Increased oxygen saturation was higher in the nesting treatment group for 7 days $(4.71 \%)$ compared to the nesting treatment group for 5 days $(2.28 \%)$.

There was a decrease in the average respiratory rate in both groups after nesting. The group that was placed nesting for 7 days $(10.57 \mathrm{x} / \mathrm{min})$ showed a mean deceleration of respiratory frequency that was more significant than the nesting group 5 days $(3.71 \mathrm{x} /$ $\min )$.

There was an increase in the weight average in both groups. The 7-day nesting treatment group experienced an increase in body weight more than 15.72 grams compared to the nesting treatment group for 5 days, which was 28.57 grams.

In both groups the results of the $\mathrm{p}$ value ( $\mathrm{p}$ value) variable oxygen saturationbefore and after the action obtained $(0.001)<\alpha(0.05)$, then H0 is rejected and H1 is accepted. So it can be concluded that the use of nesting effectively maintains oxygen saturation in premature babies.

In both groups the results of calculating the $\mathrm{p}$ value ( $\mathrm{p}$ value) variabel respiratory frequency before and after the action obtained $\mathrm{p}(0.002)<\alpha(0.05)$, then $\mathrm{H} 0$ is rejected and $\mathrm{H} 1$ is accepted. So it can be concluded that the use of nesting is effective in reducing the frequency of breathing in premature babies.

In both groups the resultl calculated the value of $\mathrm{p}$ ( $\mathrm{p}$ value) weight variable before and after the action obtained $\mathrm{p}(0.001)<\alpha(0.05)$, then $\mathrm{H} 0$ is rejected and $\mathrm{H} 1$ is accepted. So it can be concluded that the use of nesting in premature babies is effective in increasing body weight.

The nesting treatment group for 7 gave more significant results than the nesting treatment group for 5 days.

\section{REFERENCES}

Alimul. (2017). Pengantar Ilmu Kesehatan anak Untuk Pendidikan Kebidanan. Jakarta : Salemba medika

Arifah, Siti. (2010). Jurnal : Pengaruh Kangaroo Mothercare (KMC) Dua Jam Dan Empat Jam Perhari Terhadap Kenaikan Berat Badan Lahir Rendah Bayi Preterm Di RS PKU Muhammadiyah Surakarta. Surakarta : Prosiding Seminar Ilmiah Nasional Kesehatan 


\section{STRADA Jurnal Ilmiah Kesehatan}

DOI: $10.30994 /$ sjik.v9i1.275

Bayuningsih, R. (2011). Tesis : Efektivitas penggunaan nesting dan posisi prone terhadap saturasi oksign dan frekuensi nadi pada bayi prematur di RSUD Bekasi. Tidak dipublikasikan. Depok : Universitas Indonesia

Byers, et al. (2016). A Quasi-Experimental Trial On Individualized, Developmentally Suportif Family Centered Care, diakses pada tanggal 5 Maret 2019

Darmanto, Djojodibroto. (2017). Respirologi. Jakarta : EGC

Depkes RI. (2016). Pedoman Pelaksanaan Stimulasi: Deteksi, dan Intervensi Dini Tumbuh Kembang Anak Di Tingkat Pelayanan Kesehatan Dasar. Jakarta: Dirjen Bina Kesehatan Masyarakat, Depkes RI

Fleisher, B. (2016). Individualized developmental care for very low-birth-weight premature infants. USA : Diakses tanggal 7 Maret 2019

Goldsmith, J., \& Karotkin., E., H, (2013). Assistedd ventilation of the neonatal. Philadelphia : Saunders Inc

Grenier, I.R., Bigsby, R., Vergara, E, R., \& Lester, B. M. Comparasion of mootor self regulatory and stress behaviors of preterm infants across body positions. American Journal of Occupational Therapy, 57, 289-297. diundu pada tanggal 11 Maret 2019.

Guyton, A.C. (2015). Fisiologi Manusia dan Mekanisme Penyakit (edisi 3.) Jakarta: EGC

Hidayat, A. (2015). Asuhan neonatus bayi dan balita : Buku praktikum mahasiswa keidanan. Jakarta : EGC

Hockenberry, M.J, \& Wilson, D. (2017). Wong's : Nursing Care of Infants and Children. St; Louis : Mosby. Diakses tanggal 7 Maret 2019

Kenner, C., \& Mc. Grath., J.M. (2014). Developmental Care Of New Borns \& Infants: A guide For HealthProfessionalis. St. Louis: Mosby Inc

Kosim, M.S. (2011). Buku Ajar Neonatologi. Jakarta: Ikatan Dokter Anak Indonesia

Lissauer, T., Fanarrof, A. (2015). At a glance : Neonatology. USA : Mosby

MacGregor, J. (2018). Introduction to the anonimity and phisiology of children: A guide for students of nursing. child care and health (2nd edition). New York : Routledge

Merenstein, Gerald B. (2012). Neonatal Intensive Care. USA : Mosby

Nelson, B. (2011). Ilmu kesehatan anak Vol 2. Jakarta : EGC

Nursalam. (2012). Konsep Penerapan Metodologi Penelitian Ilmu Keperawatan Pedoman Skripsi, Tresis Dan Instrumen Penelitian Keperawatan. Jakarta : Salemba Medika

Pantiawati, Ika. (2015). Bayi dengan Berat Badan Lahir Rendah. Yogyakarta : Nuha Medika

Surasmi, A., Handayani, S., \& Kusuma, H.N. (2012). Perawatan Bayi Resiko Tinggi. Jakarta: EGC

Syahreni, E. (2012). Tesis : Pengaturan pengaruh stimulus sensori terhadap respon fisiologis dan perilaku BBLR di RSUPN Dr. Cipto Mangunkusumo. Depok : Universitas Indonesia

Tomey, A.M., \& Alligood, M.R. (2016). Nursing theory. Missouri : Mosby, Inc.

Widyani. (2010). Panduan Perkembangan Anak. Jakarta : Puspawarsa

Wong, Schhwartz P. (2011). Buku Ajar Keperawatan Pediatrik. (Edisi 6). Jakarta : EGC

Zubaidah. (2012). Tesis : Pengaruh Pemberian Informasi Tentang Developmental Care Terhadap Pengetahuan, Sikap dan Tindakan Perawat dalam Merawat BBLR di RSUP dr. Kariadi Semarang. Depok : FIK UI 